\title{
Change of Domicile
}

By Clive James (1939-)

Installed in my last house, I face the thought That fairly soon there will be one house more, Lacking the pictures and the books that here Surround me with abundant evidence I spent a lifetime pampering my mind. The new place will be of a different sort, Dark and austere, and I will have to find My way along its unforthcoming walls. Help is at hand here should I fall, but there There will be no-one to turn on the lights For me, and I will know I am not blind Only by glimpses when the empty halls Lead me to empty rooms, in which the nights Succeed each other with no day between.

I may not see my tattered Chinese screen Again, but I shall have time to reflect That what I miss was just the bric-a-brac I kept with me to blunt my solitude, Part of my brave face when my life was wrecked By my gift for deceit. Truth clears away So many souvenirs. The shelves come clean. In the last, the truly last house there will be No treasured smithereens to take me back To when things hung together. I'll conclude The way that I began so long ago:

With nothingness, but know it fit for me This time around, now I am brought so low, Yet ready to move soon. When, I can't say.

\section{S Linked}

- http://dx.doi.org/10.1136/bmjspcare-2014-000759 